\title{
Edukasi Pengelolaan Aset Keluarga kepada Anggota Persatuan Wanita Kristen Indonesia DIY
}

\author{
Putriana Kristanti $^{\# 1}$, Agustini Dyah Respati ${ }^{* 2}$, Purwani Retno Andalas ${ }^{\# 3}$ \\ ${ }^{\#}$ Prodi Akuntansi dan Prodi Manajemen, Universitas Kristen Duta Wacana \\ Jl. Dr. Wahidin Sudirohusodo no 5-25, Yogyakarta \\ ${ }^{1}$ putrianak@staff.ukdw.ac.id \\ ${ }^{3}$ retnoandalas@gmail.com \\ *Prodi Manajemen, Universitas Kristen Duta wacana \\ 19agustini@staff.ukdw.ac.id
}

\begin{abstract}
Abstrak-Pengabdian kepada masyarakat ini dilaksanakan melalui kerjasama antara tim pengabdian Fakulitas Bisnis Universitas Kristen Duta Wacana dengan Dewan Pimpinan Daerah Persatuan Wanita Kristen Indonesia Daerah Istimewa Yogyakarta. Pengabdian ini bertujuan untuk memberikan edukasi dan pemahaman pentingnya mengelola aset keluarga dengan baik. Edukasi ini disampaikan melalui sarana webinar yang memiliki tema "Habis Gelap Terbitlah Terang: Keluarga Sejahtera di Tengah Pandemi". Adapun sub tema yang diangkat dalam edukasi ini adalah "Pengelolaan Aset keluarga: Tips \& Trik". Peserta dari edukasi ini terdiri dari anggota dan pengurus di tingkat provinsi, kabupaten, dan kecamatan. Kegiatan dimulai dari 4 Februari sampai dengan 29 April 2021. Tim pengabdi mendampingi pengurus, khususnya Bidang Pendidikan mulai dari persiapan, pelaksanaan, sampai dengan evaluasi pelaksanaan edukasi. Metode yang digunakan dalam pengabdian ini adalah: melakukan analisis situasi, melakukan identifikasi permasalahan mitra, menentukan tujuan kerja, menyusun rencana pemecahan masalah, melakukan pendekatan sosial, melaksanakan kegiatan, serta melakukan evaluasi terhadap kegiatan dan hasil. Hasil utama pengabdian ini yaitu keluarga memahami pentingnya pengelolaan aset dengan baik, dan sekaligus mendukung kegiatan Bidang Pendidikan DPD PWKI DIY. Edukasi diperlukan untuk meningkatkan pengetahuan dan pemahaman. Pada masa pandemi edukasi dapat dilakukan secara online, melalui webinar. Edukasi terhadap para wanita (ibu) tentang pengelolaan aset keluarga akan membuat seluruh keluarga menghargai, mensyukuri dan mengelola dengan baik aset yang dimiliki oleh keluarga.
\end{abstract}

Kata kunci-aset, edukasi, keluarga, pengelolaan, PWKI.

Abstract-Title: Edukasi Pengelolaan Aset Keluarga kepada Anggota Persatuan Wanita Kristen Indonesia DIY
This community service is carried out through collaboration between the Fakultas Bisnis Universitas Kristen Duta Wacana service team and the Dewan Pimpinan Daerah Persatuan Wanita Kristen Indonesia Daerah Istimewa Yogyakarta. This service aims to provide education and understanding of the importance of managing family assets properly. This education was delivered through a webinar with the theme "After Dark Comes Light: Prosperous Families in the Midst of a Pandemic". The sub-theme raised in this education is "Family Asset Management: Tips \& Tricks". Participants of this education consist of members and administrators at the provincial, district, and sub-district levels. The activity starts from February 4 to April 29, 2021. Service team assist the management, especially in the Education Sector, from preparation, implementation, to evaluation of the implementation of education. The methods used in this service are: conducting situation analysis, identifying partner problems, determining work goals, developing problem solving plans, taking social approaches, carrying out activities, and evaluating activities and results. The main result of this service is that the family understands the importance of good asset management, and at the same time supports the activities of the DPD PWKI DIY Education Sector. Education is needed to increase knowledge and understanding. During the pandemic, education can be done online, through webinars. Education for women (mothers) about the management of family assets will make the whole family appreciate, be grateful and manage the assets owned by the family well.

Keywords: assets, education, family, management, PWKI.

\section{PENDAhUluan}

\section{A. Analisis Situasi}

Pengabdian kepada masyarakat ini dilaksanakan melalui kerjasama antara tim pengabdian Fakulitas Bisnis dengan 
DPD (Dewan Pimpinan Daerah) PWKI (Persatuan Wanita Kristen Indonesia) DIY. Pengabdian ini bertujuan untuk memberikan edukasi pemahaman pentingnya mengelola aset keluarga dengan baik. Edukasi disampaikan melalui sarana webinar dengan tema "Habis Gelap Terbitlah Terang: Keluarga Sejahtera di tengah Pandemi". Adapun sub tema yang diangkat dalam edukasi ini adalah "Pengelolaan Aset keluarga: Tips \& Trik".

Edukasi diperlukan untuk meningkatkan pengetahuan dan pemahaman, dalam hal ini diharapkan keluarga tahu dan memahami pentingnya pengelolaan terhadap aset yang dimiliki oleh keluarga. Hampir semua keluarga memiliki aset. Aset yang dimiliki melalui pembelian oleh anggota keluarga, atau melalui warisan, hibah atau pemberian oleh orang atau pihak lain. Aset yang ada perlu dijaga, dirawat, atau dikelola agar tetap bernilai tinggi dan bermanfaat dalam jangka panjang.

Keluarga telah dikarunai dan memiliki aset (harta atau kekayaan). Keluarga perlu menyadari bahwa aset merupakan sumber daya (sumber ekonomi) yang memiliki manfaat ekonomik, khususnya di masa depan. Berbagai jenis aset dimiliki oleh keluarga. Aset dengan manfaat jangka pendek (kurang atau sama dengan 12 bulan), diklasifikasikan dalam Aset Lancar. Aset yang dimiliki keluarga juga ada yang memiliki masa manfaat jangka panjang (lebih dari 12 bulan), yang diklasifikan sebagai Aset Tidak Lancar. Masing-masing aset memiliki sistem pengelolaan yang berbeda.

\section{B. Identifikasi Permasalahan Mitra}

Mitra dalam pengebdian ini adalah anggota PWKI dalam wilayah DIY, yaitu dalam wilayah Kabupaten Bantul, Kabupaten Gunungkidul, Kabupaten Kulon Progo, Kabupaten Sleman, dan Kota Yogyakarta. Adapun permasalahan mitra yang berhubungan dengan aset keluarga pada saat ini adalah pengeloaannya yang belum baik. Hal ini diperoleh melalui diskusi dalam beberapa waktu dengan kelompok diskusi (Small Grup Discussion) yang terdiri dari pengurus DPC PWKI DIY. DPC (Dewan Pimpinan Cabang) mewakili cabang-cabang yang ada dalam kabupaten dan kota dalam wilayah DIY. Pengelolaan aset yang kurang baik atau kurang tepat dapat menyebabkan kegunaan atau kemanfaatan aset tersebut menjadi berkurang atau rendah dan dengan masa manfaat yang pendek.

\section{Tinjauan Pustaka}

Aset adalah sumber daya yang dikuasai oleh entitas sebagai akibat dari peristiwa masa lalu yang memiliki manfaat ekonomik di masa depan. Sumber daya merupakan sumber ekonomi atau nilai dari suatu kekayaan atau harta. Suber daya yang diakui sebagai aset harus berada dalam kekuasaan entitas. Penguasaan dalam penggunaan, pemeliharaan, maupun pelepasannya [1].
Aset dimiliki karena adanya peristiwa di masa lalu yang menentukan diakuinya keberadaan aset tersebut. Manfaat ekonomik masa depan suatu aset adalah potensi aset tersebut dalam memberikan kontribusi secara langsung maupun tidak langsung kepada entitas [1].

Aset dapat diklasifikasikan sebagai aset lancar dan aset tidak lancar. Aset yang diklasifikasikan sebagai aset lancar adalah aset yang diperkirakan akan dimiliki untuk dijual atau digunakan dalam jangka waktu kurang atau sama dengan 12 bulan. Salah satu komponen dari aset tidak lancar adalah aset tetap dan aset takberwujud. Aset takberwujud merupakan aset yang tidak memiliki wujud. Wujud aset tidak esensial untuk menentukan keberadaan aset [1] [2].

Aset lancar mencakup yang dijual, dikonsumsi atau digunakan dalam kegiatan operasi, contoh: persediaan barang, piutang dagang. Aset lancar juga mencakup aset yang dimiliki untuk diperdagangkan, contoh: aset keuangan [2].

Aset tetap adalah aset berwujud yang dimiliki untuk digunakan dalam operasi atau penyediaan barang atau jasa untuk direntalkan kepada pihak lain, atau untuk tujuan administratif. Aset tetap diharapkan dapat digunakan selama lebih dari satu periode (12 bulan) [4]. Aset tidak berwujud adalah aset nonmoneter yang dapat diidentifikasi tanpa wujud fisik [3] contoh: merk, lisensi, paten, hak cipta.

Pengelompokan aset merujuk pada adanya sifat dan fungsi ast yang berbeda. Pengklasifikasian aset lancar dan aset tidak lancar memberikan informasi yang bermanfaat dengan membedakan aset neto yang digunakan terus menerus dari aset neto yang digunakan dalam aktivitas jangka panjang (lebih dari 12 bulan) [2]. Penelitian tentang aset lebih banyak merujuk pada aset tetap yang dikelola oleh badan negara ataupun pemerintahan daerah. Penelitian tentang pengelolaan ast daerah mengacu pada Peraturan Menteri Dalam Negeri No. 19 tahun 2016 yang berisi tentang pedoman pengelolaan barang milik daerah. Pemegang kekuasaan pengelolaan barang milik daerah adalah kepala daerah. Barang milik daerah adalah semua barang yang dibeli atau diperoleh atas beban APBD atau berasal dari perolehan lainnya yang sah. Pengelolaan barang milik daerah adalah keseluruhan kegiatan yang meliputi perencanaan kebutuhan dan penganggaran, pengadaan, penggunaan, pemanfaatan, pengamanan dan pemeliharaan, penilaian, pemindahtanganan, pemusnahan, penghapusan, penatausahaan dan pembinaan, pengawasan dan pengendalian. [5]

[6] Pelaksanaan pengelolaan aset tetap yang sesuai dengan peraturan menteri dalam negeri yang berlaku adalah baik, dengan dilaksanakan secara lengkap. [7] Aset tetap yang dikelola dengan baik akan menghasilkan informasi yang andal. Pengelolaan aset dengan tertib berdampak secara signifikan terhadap sempurnanya informasi yang 
disampaikan. Koordinasi yang baik dengan semua pengelola dan pengguna aset sangat dibutuhkan.

[8] Kepemilikan secara legal berpengaruh secara positif dalam optimalisasi pengelolaan aset. Supervisi dan pengendalian terhadap aset juga memiliki pengaruh yang sama.

[9] Pengelolaan aset desa dalam peningkatan kesejahteraan dan mengamati faktor penghambat dalam pengelolaan aset desa. Pelaksanaan dan pengawasan yang belum berjalan dengan baik akan menghasilkan kurang maksimalnya peningkatan kesejahteraan. Salah satu faktor penghambat yang terlihat dalam pengamatan adalah sumber daya manusia yang kurang memiliki pengetahuan dalam pengelolaan aset desa.

[10] Faktor-faktor yang mempengaruhi pengelolaan setelah ekspansi dan pengaruhnya terhadap kualitas dari laporan keuangan. Hasil penelitian menunjukkan bahwa pengetahuan sumber daya manusia terhadap pengelolaan aset, bukti kepemilikan aset, penilaian aset, komitmen kepemimpinan, dan sikap berpengaruh pada timbulnya kesadaran dan tanggung jawab.

\section{Tujuan Pengabdian}

Pengabdian ini bertujuan untuk memberikan edukasi pemahaman pentingnya mengelola aset keluarga dengan baik. Pengelolaan aset dengan baik sangat diperlukan dengan tujuan utamanya adalah untuk menjaga agar nilai aset tetap tinggi dan memiliki umur manfaat yang panjang. Tujuan lainnya antara lain adalah untuk memastikan status kepemilikan dari aset yang ada. Aset tersebut milik kita atau milik pihak lain. Inventarisasi aset dan umur manfaat masing-masing aset. Pemanfaatan aset secara optimal.

Penyelenggaraan pengelolaan aset perlu memperhatikan siklus pengelolaan yang terdiri dari: (1) perencanaan aset yang akan dimiliki dan digunakan; (2) pengadaan aset sesuai dengan yang telah direncanakan; (3) inventarisasi aset yang dimiliki; (4) legal audit aset.; (5) pengoperasian dan pemeliharaan aset; (6) penilaian aset; (7) pembaruan aset; (8) penghapusan aset. Setiap tahapan siklus perlu diperhatikan dan dilaksananakan secera berurutan.

Pengelolaan aset lebih baik dilaksanakan melalui sistem. Sistem pengelolaan aset dapat diterapkan melalui pemahaman terhadap siklus hidup aset, pemilihan penganggung jawab aset, pengetahuan terhadap penyusutan aset, dan cek terhadap aset yang dimiliki.

\section{Metode Pengabdian MasyaraKat}

Metode Pengabdian kepada Masyarakat yang diterapkan dalam pengabdian ini meliputi tahapan-tahapan sebagai berikut:

\section{A. Identifikasi Masalah}

Identifikasi masalah merupakan hasil dari tahap analisis situasi yang telah dilakukan sebelumnya. Hasil analisis menyimpulkan adanya pengelolaan aset yang belum baik oleh mitra. Hal ini disebabkan adanya kurangnya pengetahuan dan pemahaman terhadap pengelolaan aset keluarga dengan baik.

Dari beberapa referensi di atas menunjukkan bahwa kurangnya pengetahuan terhadap pengelolaan aset akan menyebabkan kurangnya kesadaran dan tanggung jawab terhadap pemanfaatn dan pengelolaan aset secara menyeluruh.

Mitra dalam pengabdian ini adalah para wanita yang sebagian besar berperan sebagai ibu dalam rumah tangga. Para wanita atau ibu-ibu dalam komunitas ini merupakan sumber daya yang luar biasa dalam sebuah keluarga. Mereka menjadi salah satu pengelola maupun pemakai yang potensial dari seluruh aset yang dimiliki oleh keluarga. Mereka akan menjadi kekuatan yang luar biasa dalam keluarganya untuk menuju keluarga yang lebih sejahtera.

\section{B. Menentukan Tujuan Kerja}

Tujuan kerja dari pengabdian ini adalah memberikan tambahan pengetahuan tentang pengelolaan aset sebagai salah satu upaya untuk meningkatkan kesejahteraan keluarga. Pengetahuan yang bertambah diharapkan dapat meningkatkan kesadaran dan tanggung jawab. Dalam hal ini penambahan pengetahuan tentang pengelolaan aset keluarga diharapkan dapat mempengaruhi keluarga untuk memiliki dan kesadaran dan tanggung jawab dalam pengelolaan aset.

Penambahan pengetahuan dilakukan melalui edukasi. Edukasi yang terbatas, disebabkan masih adanya pandemi covid-19 yang menyebabkan terbatasnya interaksi dan komunikasi.

\section{Rencana dan Pelaksanaan Pemecahan Masalah}

1) Mencari Alternatif Pemecahan Masalah: Beberapa alternatif dalam pemecahan masalah diidentifikasi bersama dengan perwakilan dari mitra, yaitu pengurus PWKI tingkat propinsi, kabupaten dan kota, serta kecamatan. Beberapa alternatif ditentukan, kemudian dipilih yang memungkinkan untuk dilaksanakan dalam masa pandemi ini. Pemecahan masalah dapat dilakukan melalui pelatihan dan edukasi.

2) Memilih alternatif yang terbaik: Alternatif pemecahan yang dipilih adalah penambahan pengetahuan kepada anggota PWKI melalui edukasi dengan sarana webinar. Pelatihan sebenarnya lebih baik dari edukasi melalui webinar, akan tetapi dikarenakan masih dalam masa pandemi covid-19 yang tidak dimungkinkan adanya pertemuan secara fisik, maka pengabdian lebih mungkin dilakukan melalui edukasi dengan sarana webinar.

\section{Pendekatan Sosial}

Pendekatan sosial dimaksudkan sebagai pendekatan terhadap mitra. Mitra sasaran diposisikan sebagai subyek 
dari kegiatan pengabdian ini. Kelompok mitra sebanyakbanyaknya dilibatkan dalam kegiatan, termasuk dalam proses perencanaan kegiatan. Semua pihak yang akan menjadi subyek program pengabdian ini dijadikan sasaran pendekatan. Kelompok mitra ditumbuhkan kesadarannya bahwa masalah itu adalah masalah mereka, yang perlu untuk dipecahkan sendiri atau bersama pihak lain.

Pendekatan sosial dalam program pengabdian ini dilakukan melalui pendekatan sosial dengan melibatkan seluruh komponen kelompok mitra dan para pemangku kepentingan yang merupakan bagian dari lingkungan sosial mitra program ini. Area meliputi seluruh Propinsi DIY.

Edukasi yang dilakukan melalui webinar memungkinkan keterlibatan lebih dari mitra. Masyarakat umum dan anggota PWKI di luar DIY juga diberi kesempatan untuk bergabung dalam webinar ini.

\section{E. Pelaksanaan Kegiatan}

1) Bentuk Kegiatan : Kegiatan edukasi disampaikan melalui webinar. Pertemuan tidak secara langsung dikarenakan masih dalam masa pandemi covid-19. Hal ini justru memungkinkan pengabdi untuk menjangkau area yang lebih luas, tidak terbatas oleh wilayah dan jumlah peserta. Webinar diselenggarakan dengan menggunakan sarana zoom meeting. Publikasi dilakukan dengan sharing poster rencana kegiatan kepada grup-grup whatchapp pimpinan pusat, daerah, cabang dan anak cabang.

2) Waktu Pelaksanaan Kegiatan: Kegiatan dimulai dari perencanaan yang dilaksanakan mulai tanggal 4 Februari 2021, pelaksanaan webinar tanggal 23 April 2021, dan evaluasi pada tanggal 29 April.

3) Tempat Pelaksanaan Kegiatan: Pertemuan-pertemuan mulai dari pembahasaan perencanaan sampai dengan pelaksanaan dan evaluasi dilaksanakan melalui grup chat WhatsApp, Google Meet, dan Zoom meeting room, dikarenakan masih dalam masa pandemi dan PPKM (Pemberlakuan Pembatasan Kegiatan Masyarakat).

4) Pihak-pihak yang akan Dilibatkan dalam Kegiatan: pengurus dan anggota PWKI wilayah propinsi DIY sampai dengan kecamatan, PWKI di luar DIY, serta masyarakat umum. Dalam penentuan pelaksanaan kegiatan tersebut pendapat dan saran dari kelompok sasaran sangat diperhatikan.

\section{F. Evaluasi Kegiatan dan Hasil}

Evaluasi kegiatan dalam setiap tahapan serta upaya penyempurnaan dilakukan selama proses pelaksanaan pengabdian berlangsung. Evaluasi mengikutsertakan kelompok mitra. Proses ini merupakan bentuk pertanggungjawaban dari segala sesuatu yang telah dilakukan dalam program pengabdian kepada masyarakat.

Berdasarkan hasil evaluasi maka ditentukan program kerja selanjutnya.

\section{TARGET DAN LUARAN}

Tema besar yang menaungi kegiatan ini adalah "Habis Gelap Terbitlah Terang: Keluarga Sejahtera di tengah Pandemi". Adapun sub tema yang diangkat dalam edukasi ini adalah "Pengelolaan Aset keluarga: Tips \& Trik".

Tema dan sub tema tersebut ditentukan secara bersamasama dengan mitra, berdasarkan kebutuhan dari mitra. Masa pandemi yang semula terlihat gelap kita upayakan untuk berubah menjadi terang. Keluarga sejahtera menjadi target dari kegiatan ini.

Keluarga sejahtera salah satunya kita upayakan melalui pengeloaan aset keluarga dengan baik, yang akan meningkatkan manfaat dari aset yang dimiliki oleh keluarga, yang pada akhirnya kita harapkan dapat meningkatkan kesejahteraan keluarga.

Edukasi akan menambah pengetahuan dan pemahaman pentingnya pengelolaan aset dengan baik.

Luaran dari kegiatan pengabdian ini antara lain adalah: (1) format edukasi yang dapat dilaksanakan dalam masa pandemi; serta (2) menghasilkan bahan pembelajaran dan laporan pengabdian.

\section{HASIL DAN PEMBAHASAN}

\section{A. Edukasi}

Edukasi menurut KBBI sama artinya dengan pendidikan. Pendidikan diartikan sebagai proses pengubahan sikap dan tata laku seseorang atau kelompok orang dalam usaha mendewasakan manusia melalui upaya pengajaran dan peralihan, proses, cara, perbuatan mendidik.

Hasil dari edukasi dalam pengabdian ini adalah mengubah sikap dan tata laku mitra terhadap pengelolaan aset. Edukasi yang dilakukan diharapkan membuat mitra lebih bersikap dewasa dan bijaksana.

Hasil penelitian [10] menunjukkan bahwa pengetahuan sumber daya manusia terhadap pengelolaan aset, bukti kepemilikan aset, penilaian aset, komitmen kepemimpinan, dan sikap berpengaruh pada timbulnya kesadaran dan tanggung jawab.

Edukasi yang diberikan dalam pengabdian ini menambah pengetahuan para wanita atau ibu-ibu dalam organisasi PWKI sehingga menimbulkan adanya kesadaran dan tanggung jawab yang lebih dalam mengelola aset. Para ibu yang berpengetahuan ini akan mengimplementasikan dalam kehidupan masing-masing keluarga. Para ibu juga akan mendidik segenap anggota keluarga dalam rumahnya (anak, suami, dan saudara) untuk senantiasa melakukan pengelolaan aset keluarga dengan baik, sehingga akan meningkatkan kemanfaatan dari masing-masing aset, serta memberikan kontribusi dalam kehidupan keluarga yang akan meningkatkan kesejahteraan keluarga.

\section{B. Pengelolaan Aset}


Sejalan dengan peraturan Menteri Dalam Negeri Nomor 19 Tahun 2016 tentang pengelolaan barang milik daerah, maka pengelolaan aset keluargapun hampir sama, yaitu seluruh kegiatan yang meliputi:

1) Perencanaan Kebutuhan: Kegiatan pengelolaan aset dimulai dengan merencanakan kebutuhan akan aset. Kebutuhan dari ayah, ibu, dan anak-anak. Identifikasi dari aset yang dibutuhkan berdasarkan pertimbangan akan: kegunaan dan kemanfaatannya, aset yang sudah dimiliki, dan konsekuensi dari kepemilikan aset yang akan dibeli. Seyogyanya seluruh anggota keluarga membicarakan dan mendiskusikan bersama aset-aset yang dibutuhkan dalam waktu dekat maupun waktu panjang.

2) Penganggaran: Setelah ditentukan kebutuhan akan aset, maka disusun anggarannya sesuai dengan kemampuan yang dimiliki oleh keluarga. Anggaran akan menentukan jumlah dana yang dibutuhkan. Selain menyusun menghitung dana yang dibutuhkan, juga dipirkirkan sumber dana dari pengadaan aset tersebut. Dana dari tabungan sendiri atau semua atau sebagian menggunakan pinjaman.

3) Pengadaan: Berdasarkan anggaran dan dana yang dimiliki, kemudian dilakukan pengadaannya. Pengadaan aset mempertimbangkan merk barang, kualitas, pemasok, dan pelayanan purna jual.

4) Penggunaan: Setelah aset dimiliki maka diatur penggunaannya. Penggunaan harus diawasi dan dikendalikan, serta diatur agar penggunaannya tidak berlebihan. Penggunaan aset yang berlebihan akan menyebabkan aset mudah rusak. Koordinasi dalam penggunaan aset akan memaksimalkan penggunannya.

5) Pemanfaatan: Pastikan bahwa keluarga memanfaatkan dengan baik seluruh aset yang ada. Secara periodik perlu dievaluasi sejauh mana aset yang ada bermanfaat bagi keluarga.

6) Pengamanan dan pemeliharaan: Aset keluarga harus dijaga keamanannya supaya tidak mudah rusak ataupun hilang. Aset harus senantiasa aman dari hal-hal yang tidak diinginkan. Pemeliharaan aset harus dilakukan rutin.

7) Penilaian: Secara periodik aset perlu dinilai untuk mengetahui seberapa bernilainya aset yang kita miliki.

8) Pemindahtanganan: Beberapa aset kemungkinan sudah tidak kita perlukan lagi, sehingga bisa kita pindahtangankan kepada orang lain. Pemindahtangan bisa melalui penjualan atau pemberian atau dihibahkan kepada yang memerlukannya.
9) Pemusnahan: Beberapa aset bahkan mungkin perlu dimusnahkan dengan alasan tertentu.

10)Penghapusan: Aset yang sudah dipindahtangankan ke pihak lain, aset yang sudah dimusnahkan, dan aset yang tidak digunakan sebaiknya dihapus dari daftar inventaris keluarga.

11)Penatausahaan: Catatan terhadap kondisi aset diperlukan, misal catatan tentang harga perolehan, waktu pembelian, waktu penggunaan, jumlah aset Catatan yang baik akan menghasilkan informasi yang baik. Informasi yang baik akan memudahkan dalam pengelolaan aset.

12)Pengawasan dan pengendalian: Aset harus senantiasa diawasi agar tidak terjadi kerusakan, kehilangan, atau penyalahgunaan. Penggunaan, pemeliharan dan pemanfaatan masing-masing aset perlu dikendalikan dengan baik.

\section{Edukasi Pengelolaan Aset}

Berikut ini dijelaskan tentang hubungan edukasi dengan pengelolaan aset, serta pengaruh dan hasil dari edukasi tentang pengelolaan aset.

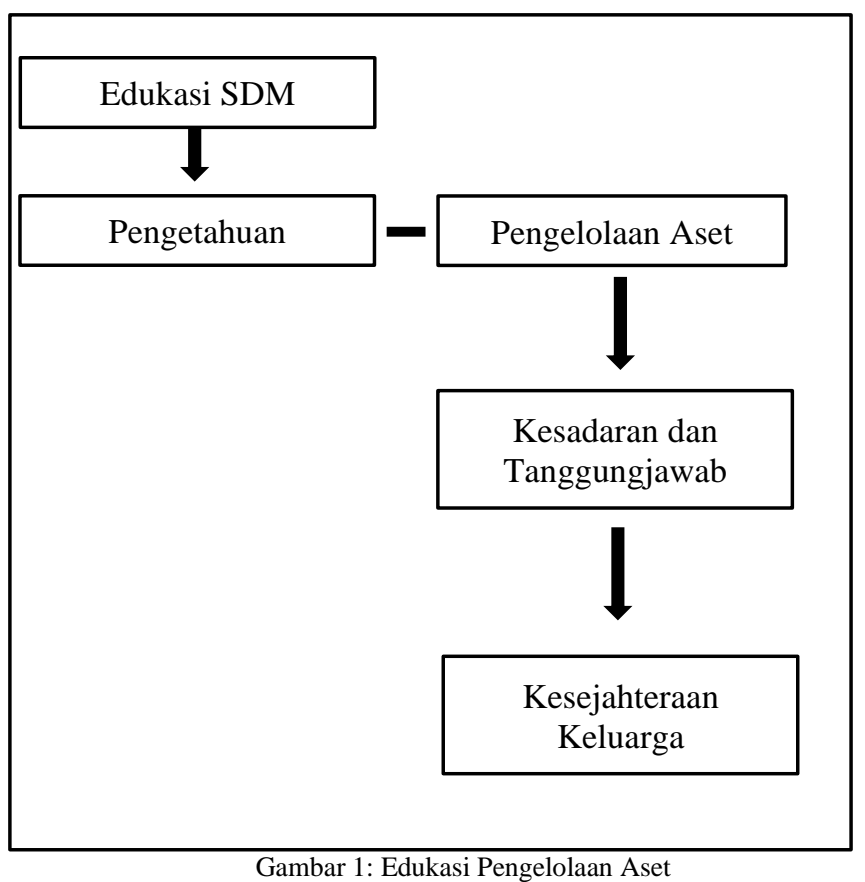

Edukasi diberikan kepada sumber daya manusia, dalam hal ini adalah kepada anggota PWKI, yang semuanya adalah wanita dan sebagian besar adalah ibu. Edukasi menambah pengetahuan. Edukasi pengelolaan aset memberikan kepada para ibu pengetahuan tentang pengelolaan aset keluarga. Pengetahuan yang diterima akan menimbulkan dan 
menambahkan kesadaran dan tanggung jawab para ibu dalam mengelola aset milik keluarga.

Pengetahuan, kesadaran dan tanggungjawab yang dimiliki oleh para ibu ini akan ditularkan kepada segenap anggota keluarganya. Koordinasi dalam keluarga mengelola asetnya sangat dibutuhkan untuk meningkatkan kemanfaatan dari aset yang dimiliki oleh keluarga.

Keluarga yang dapat mengelola asetnya dengan baik akan dapat memanfaatkan asetnya dengan baik pula, yang pada akhirnya akan mengarah pada meningkatnya kesejahteraan keluarga. Kesejahteraan keluarga inilah yang menjadi target dari diselenggarakannya pengabdian ini.

\section{KESIMPULAN}

Mitra dalam pengabdian ini adalah anggota dan pengurus PWKI dalam wilayah propinsi DIY, yang semuanya adalah wanita, dan sebagian besar adalah ibu. Edukasi kepada para ibu ini diharapkan akan dapat meningkatkan kesejahteraan keluarga. Khususnya edukasi tentang pengelolaan aset keluarga. Pengetahuan akan menimbulkan dan menambahkan kesadaran dan tanggung jawab para ibu dalam mengelola aset milik keluarga.

Koordinasi anggota keluarga dalam mengelola asetnya akan meningkatkan kemanfaatan dari aset yang dimiliki oleh keluarga. Keluarga yang dapat mengelola asetnya dengan baik akan dapat memanfaatkan asetnya dengan baik pula, yang pada akhirnya akan mengarah pada meningkatnya kesejahteraan keluarga.

\section{UCAPAN TERIMA KASIH}

Ucapan terima kasih pengabdi sampaikan kepada Fakultas Bisnis Universitas Kristen Duta Wacana yang telah memberikan kesempatan dan mendanai pengabdian kepada masyarakat ini. Terima kasih juga kami sampaikan kepada pengurus PWKI yang telah bersedia menjadi mitra dari pengabdian ini.

\section{DAFTAR PUSTAKA}

[1] IAI. 2016. Standar Akuntansi Keuangan Entitas Mikro, Kecil, dan Menengah. Jakarta: Ikatan Akutansi Indonesia.

[2] IAI. 2018a. Standar Akuntansi Keuangan: Pernyataan Standar Akuntansi Keuangan 1 (Revisi 2009). Jakarta: Ikatan Akutansi Indonesia.

[3] IAI. 2018b. Standar Akuntansi Keuangan: Pernyataan Standar Akuntansi Keuangan 19 (Revisi 2009. Jakarta: Ikatan Akutansi Indonesia.

[4] IAI. 2018c. Standar Akuntansi Keuangan: Pernyataan Standar Akuntansi Keuangan 16. Jakarta: Ikatan Akutansi Indonesia.

[5] Peraturan Mendagri. 2016. Peraturan Menteri Dalam Negeri Republik Indonesia Nomor 19 Tahun 2016 tentang Pedoman Pengelolaan Barang Milik Daerah. Bab 1 Pasal 1.

[6] Kurniawan , I . 2021. Analisis Pengelolaan Aset Tetap pada Badan Pengelolaan Keuangan dan Aset Daerah Kabupaten Kuantan Singingi Teluk Kuantan. Juhan Perak, vol. 2, no. 1, pp. 229-239.

[7] Kolinug, M. Sutri, V. Ilat, and S. Pinatik, 2015. Analisis Pengelolaan Aset Tetap pada Dinas Pendapatan Pengelolaan Keuangan dan Aset Daerah Kota Tomohon. J. Ris. Ekon. Manajemen, Bisnis dan Akunt., vol. 3, no. 1, pp. 818-830.

[8] Pratama, M. Rizky, and B. Pangayow. 2016. Pengaruh Manajemen Aset terhadap Optimalisasi Pengelolaan Aset daerah Studi Pada Pemerintah Kota Jayapura. J. Akunt. Keuang. Drh., vol. 11, no. 2, pp. 33-51.

[9] Dewi, R. 2017. Pengelolaan Aset Desa dalam Upaya Meningkatkan Kesejahteraan di Desa Krayan Bahagia Kecamatan Long Ikis Kabupaten Paser. E-journal Ilmu Pemerintah., vol. 5, no. 1, pp. 199-212.

[10] Simamora, Rudianto, and A. Halim. 2012. Faktor-Faktor Yang Mempengaruhi Pengelolaan Aset Pasca Pemekaran Wilayah dan Pengaruhnya terhadap Kualitas Laporan Keuangan Pemerintah di Kab. Tapanuli Selatan. J. Ekon. Dan Bisnis, vol. 10, no. 01, pp. 47-61. 